\title{
The Role of Internal Control to Prevent the Fraud in Small and Micro Enterprises: A Turkish Perspective
}

\author{
AtillaBüyükçoban ${ }^{1}$, Dr.GülümserÜnkaya ${ }^{2}$ \\ ${ }^{I} I A U$, Institute of SocialSciences, Business Management PhDStudent, IndependentAccountantand Financial \\ ${ }^{2} I A U$, IIIBF, Lecturer of Accounting and Finance Management Department,
}

\begin{abstract}
The main purpose of this study is to evaluate the inability of internal control systemon preventing the fraud according toTurkey's Small and Micro Enterprises. It is a known fact that the fast growing SMEs have an important role in Turkey's economy with their global work opportunities. Due to their financial problems, Small and Micro Enterprisescould see the internal control system as an important cost element. Although it may be hard to establish an effective internal control system in such enterprises, with the study conducted, it has been tried to understand the perception and attitude of SME representatives about internal control system and its role on preveting the fraud.
\end{abstract}

\section{Introduction}

Definitions of small and microenterprises (SMEs) could be based on number of employees, capital investment, product or service turnover, net worth, sales volume, range of markets, or amount and type of energy used in production (Hunt, 1983). Most commonly, the measuring criterion is number of employees (Hyman, 1989). MostSMEsare in theinformalsector of theeconomy, whichincludesmanufacturingand service enterprises, many of whicharepart-time, seasonal, oritincrant. Theseenterprises do not have a businesslicenseor a recognized legal identity. Usually, theinformalsector is outsidethescope of governmentregulations on minimum wagesandbusinesstaxes, but it faces market competition. SMEsmakeimportantcontributions in manyeconomies in theworld (Bowen, Morara, \&Mureithi, 2009; Gjini, 2014; Robson, Haugh, \&Obeng 2009). Accordingly, SMEscontributetoeconomicgrowth, reduceunemploymentandensure an equitabledistribution of income (Gjini, 2014). Similarly, Robson et al. (2009) andZindiye (2008) submitthatSMEs set the foundation for the creation of thecountry'swealth as well as economicgrowth. SMEs also have an important market share in Turkey. Thanks to their ability and speed of adaptation towards changes, flexible structure, low cost and diverse business models within the limited labor market, they have the possibility of rapidly responding to the needs of market conditions and economic changes (Cabarrouy, 1999). SMEs are also rapidly developing companies in the global economy thus creating new job opportunities. Most of the countries define SMEs by classifying them as small or medium-sized enterprises, depending on the number of shares and employees in the manufacturing sector. The description of SME in EU legislation is as follows: "The enterprises with less than 250 workers, with the annual income up to 50 million euros or with a balance sheet size up to 43 million euros are considered as SMEs" (Aksoy, 2007). If the description of SME in EU legislation is taken as a basis, a vast majority of the enterprises in Turkey may be defined as SMEs (Argun, 2009). An enterprise considered big in developing countries may fit into the group of medium or small-sized enterprises of developed countries. When it is considered from this aspect, since most of Turkey's enterprises are made by SMEs and they have an important role on the economic development with tax contribution and employment they create and, they are worth investigating in many aspects.

Due to the financial problems, SMEs may arrange fraudulent financial statements to increase their creditworthiness in front of the credit institutions. The enterprise's inability to provide satisfying wages to its employees, once again due to financing problems, may motivate its employees to commit fraudulent acts and corruption. In general, in enterprises, the employee wages are declared not by their actual value, but by minimum rate. This situation causes taxation loss of the state via SMEs. These frauds in question have become critical because of the vastness of tax loss and the liabilities it causes for the auditors (Ramos, 2003). Although establishing an effective internal control system may seem to be costly for SMEs, preventing frauds and corruption is only possible by having an internal control system. Accordingly, this study is based on determining the importance of the internal control system for fraud and corruption prevention from the point of view of SMEs.

\section{Internal Control System}

It has longbeenarguedthatthe size of operation sand the small number of employees in small enterprises affects the designing of a system of internal control for such enterprises. According to Grollmanand Colby (1978), internalcontrols in small enterprises are affected by special problemsinherent in small enterprises. These 
problems typify the characteristics of the typical small enterprise which include little ornosegregation of duties due to the small number of employees, simple record keeping, limit edinternal control sand the potentialformanagementoverride (GrollmanandColby, 1978). Internal control is a consulting service, performed independently and impartially, in order to improve and increase the value of the activities carried out by an enterprise. Functioning in a systematical and disciplined manner, by testing and increasing the efficiency during risk management and control phases, internal control contributes to achieving its objectives by an enterprise (TIDE, 2010). In order to detect or prevent any fraud, an enterprise has to establish an efficient internal control system in the accounting process (Foster, et al., 2010). Accounting control, coordinated by the related enterprise in order to ensure the precision and credibility of accounting statements, is a part of the internal control system, which covers organizational structure, methods and measurements (Manurung et al., 2015). Internal control is a system established with the purpose of securing the execution of the activity and efficiency of operations, the authenticity and legitimacy of account currents (COSO, 2015).COSO describes internal control as follows: "Establishing a common structure so as to meet the needs of different departments of the same enterprise; establishing a control system procedure, without the aim of getting profit or not thinking about profit, without discriminating small or big enterprises and in accordance with the criteria predetermined by public or private enterprises and aiding this structure to advance" (Atmaca, 2012). COSO report sees the benefit in using SMEs' financial reporting with the intention of improving the quality, the level of internal control and institutionalization. The internal control system is a necessity in order to prevent malfunctioning of enterprise transactions and help the enterprise attain its predetermined objectives. Therefore, the main goal of the enterprise, "staying alive", is indeed largely related to the good management of internal control system (Amudo and Inanga, 2009). Enterprises need the internal control system to maintain the errors made during the registration of financial information, shortcomings experienced in the productive usage of funds, and fraud and risk concepts at the lowest level (Türedi et al., 2015).

No matter what the size of the enterprise is, a vast majority of data presented to analyze and make a decision about enterprises is provided by the accounting system. Many groups and foundations are closely interested in the information and data provided by the accountancy, as it is a tool of management. It is impossible for the directors to make a management decision without making use of the financial data. Nowadays, accounting is no longer a system which only records the past events. Accounting has turned into an effective tool of management, which allows the preplanning of activities and accurate analyzing of the results (Salık, 2015). Accounting information system functions by recording the operating activities, thus drawing attention directly to problems and aiding the management with decision making and assisting in the solution of the problem (Kalmış et al., 2006 and Çelik and Akgemici, 2010). Therefore, the accounting information system provides the expected quality information. The activity of internal control system has a great importance on SMEs' confidence future. However, the inadequacy of SMEs' budgets and the cost of internal control system create an obstacle for SMEs to activate their internal control system. Less logistic and structured condition of internal control in SMEs does not diminish the value and effectiveness of internal control. Therefore, the positive impact of internal control systems on organizational effectiveness, productivity and prolificacy cannot be ignored, both in small, and big enterprises (Sgardea, 2009). With an effective internal control system, SMEs' existence is protected, resources are used actively and effectively, the reliability of financial statements is ensured, and the risk of fraud and corruption in the enterprise is reduced.

\section{Fraud}

Fraud is a concept that has come into existence in the last two hundred years and is knowninthe public as finance based fraud. The usage of manipulation of people or fraud to gain money, land, assets or trust can be traced even to the earliest periods of world history. The establishment of accounting and audit by the will of the government to prevent theft and false declarationis connectedwith the history of economics(Petraşcu and Tieanu, 2014). Fraud is mostly performed in financial reporting. Itis an act which causes a loss of trust of the economic system, threatens the democratic structure, weakens the social stability, causesbig financial losses and negatively affects the economy as a whole (Nicolescu C., 2007).American Commission established in order to investigate fraudulent financial reporting describes fraud as follows: "any act presenting financial statements in a false way to a significant extent." In real terms, the noun defined as fraud means making changes in documents and certificates, making fictive records by deleting records or destroying important data(Stolowy and Breton, 2004). Theresearchesconducted show that an effective internal control system plays a critical role in fraud prevention and detection (Othman et al., 2015).

\section{Material and Method}

In order to investigate the effect of the internal control in SMEs in fraud prevention, the owners, managers, and accounting, finance employees of SMEs, which are situated in Istanbul but work in different sectors, were observed. Since it is not possible to observe this populationdue to the time and budget constraint, 
The Role of Internal Control to Prevent the Fraud in Small and Micro Enterprises: A Turkish....

186 SMEs owners, managers, and accounting, finance employees, which are thought to represent this universe well, were determined as a sample by the convenience sampling method. Datawere collected either by meeting, using the Internet or via mail. In the personal information form, there are questions involving gender, age, educational level, experience in the enterprise, the legal structure of the enterprise and the number of employees of the enterprise. The questionnaire consists of eighteenitems for the role of internal control system in SMEs in fraud and corruption prevention.All items were graded according to the 5-point Likert scale. The meaning of the numbers is as follows: 5; strongly agree, 4; agree, 3; undecided, 2; disagree and 1; strongly disagree. The scale has been reliable since the $93 \%$ Cronbach Alpha value. SPSS software was used to analyze the data. To determine the current status of observed SMEs, frequency tables were obtained and main descriptive statistics were calculated. To test the relationship between the existence of internal control system and fraud, an independence samples t-test was applied.

\section{Results And Conclusion}

Table-1 demonstrates the distribution of the participants according to their demographic characteristics.

Table-1 Distribution According to Demographic Characteristics

\begin{tabular}{|c|c|c|c|}
\hline & & $\mathrm{n}$ & Percentage \\
\hline \multirow[t]{3}{*}{ Gender } & Male & 124 & 66,7 \\
\hline & Female & 62 & 33,3 \\
\hline & Total & 186 & 100 \\
\hline & & $\mathbf{n}$ & Percentage \\
\hline \multirow[t]{6}{*}{ Education } & High school & 3 & 1,6 \\
\hline & Associate Degree & 17 & 9,2 \\
\hline & Bachelor's Degree & 87 & 47 \\
\hline & Master Degree & 68 & 36,8 \\
\hline & Ph.D. and above & 11 & 5,4 \\
\hline & Total & 186 & 100 \\
\hline & & $\mathbf{n}$ & Percentage \\
\hline \multirow[t]{7}{*}{ Experience } & Less than 1 year & 7 & 3,8 \\
\hline & $1-5$ years & 63 & 33,9 \\
\hline & $5-10$ years & 54 & 29 \\
\hline & $10-15$ years & 21 & 11,3 \\
\hline & $15-20$ years & 16 & 8,6 \\
\hline & More than 20 years & 25 & 13,4 \\
\hline & Total & 186 & 100 \\
\hline \multirow[t]{2}{*}{ Age } & Average & 45 & \\
\hline & Standard Deviation & 23 & \\
\hline
\end{tabular}

When the distribution of the managers who have participated in the survey is examined according to demographic characteristics, it is seen that a big partof the sampleconsists of male managers. In terms of education, a big part of the sample consists of bachelor's and master degree holders, and it is seen that a numberof high school graduates isvery low. When the managers are evaluated according to their experience, a big part of the sample consists of the managers with the experience between 1 and 10 years, and it is seen that the percentage of managers with less than 1 year of experience is considerably low. The fact that the average age is not very low shows parallelism with the distribution of the group according to the experience.

Table-2 demonstrates the distribution of the represented enterprises according to their general characteristics.

Table-2Distribution of Enterprises According to the General Characteristics

\begin{tabular}{|l|l|l|l|}
\hline \multicolumn{2}{|c|}{} & $\mathrm{n}$ & Percentage \\
\hline \multirow{4}{*}{ Legal Structure } & Publicly Held Company & 22 & 11,8 \\
\cline { 2 - 4 } & Privately Held Company & 61 & 32,8 \\
\cline { 2 - 4 } & Limited Company & 75 & 40,3 \\
\cline { 2 - 4 } & Others & 28 & 14,5 \\
\hline Total & Service & 186 & 100 \\
\hline \multirow{3}{*}{ Sector } & Production & 79 & 43,2 \\
\cline { 2 - 4 } & Commerce & 56 & 30,6 \\
\hline Total & Less than 1 million TL & 26,2 \\
\hline \multirow{3}{*}{ Annual Sales } & Between 1-5 million TL & 46 & 20,1 \\
\cline { 2 - 4 } & Between 6-10 million TL & 186 & 17,3 \\
\cline { 2 - 4 } & Between 11-20 million TL & 36 & 21,8 \\
\cline { 2 - 4 } & Between 21-25 million TL & 31 & 17,3 \\
\hline Total & Less than 1 million TL & 39 & 23,5 \\
\hline \multicolumn{2}{|l|}{ Total Assets } & 31 & 100 \\
\hline
\end{tabular}


The Role of Internal Control to Prevent the Fraud in Small and Micro Enterprises: A Turkish....

\begin{tabular}{|c|c|c|c|}
\hline & Between 1-5 million TL & 64 & 36 \\
\hline & Between 6-10 million TL & 18 & 10,1 \\
\hline & Between 11-20 million TL & 19 & 10,7 \\
\hline & Between 21-25 million TL & 27 & 15,2 \\
\hline \multicolumn{2}{|l|}{ Total } & 178 & 100 \\
\hline \multirow{2}{*}{$\begin{array}{l}\text { Independent Member of } \\
\text { the Board of Directors }\end{array}$} & Yes & 96 & 52,2 \\
\hline & No & 88 & 47,8 \\
\hline \multicolumn{2}{|l|}{ Total } & 184 & 100 \\
\hline \multirow[t]{2}{*}{ Audit Committee } & Yes & 105 & 57,1 \\
\hline & No & 79 & 42,9 \\
\hline \multicolumn{2}{|l|}{ Total } & 184 & 100 \\
\hline
\end{tabular}

Considering the distribution of the enterprisesaccording to their general characteristics, having close numbers of enterprises in the sub-categories of each characteristic is considered to create a possibility of working with a homogenous structure while evaluating the scales. Therefore, the results obtained can be generalized for enterprises of different sectors, with different economic, organizational and legal structures. When the enterprises are analyzed according to the number of employees, the average number of employees is 167 , and its standard deviation is 804 . That the standard deviationis extremely high indicates the fact that the enterprises differ in terms ofthe number of employees, and the variable is very high at this point.

Table-3 Questionnaire Items and Descriptive Statistics

\begin{tabular}{|c|c|c|c|}
\hline & $\mathrm{N}$ & Mean & Std. Dev. \\
\hline Numericalerrorsperiodicallyoccur in theaccountingrecords. & 184 & 3,0 & 1,6 \\
\hline A transaction is sometimesrecordedtoanotheraccountinstead of thecorrectaccount. & 184 & 3,1 & 1,7 \\
\hline Althoughthe name of theaccount is correctlydetected, a transaction is sometimesrecordedadverse. & 184 & 3,5 & 1,4 \\
\hline Incorrectandencounteredfraudulentdocumentsperiodicallyoccur. & 183 & 3,7 & 1,4 \\
\hline Duplicaterecordsperiodicallyoccur. & 181 & 3,2 & 1,5 \\
\hline Orderedanddeliveredgoodsaresometimesdifferentfromrequestedgoods. & 183 & 2,3 & 1,3 \\
\hline Ineligiblepaymentsperiodicallyoccur. & 184 & 4,0 & 1,2 \\
\hline Incorrectacrualperiodicallyoccurs. & 184 & 3,1 & 1,3 \\
\hline Redundantpaymentsperiodicallyoccur. & 182 & 3,9 & 1,4 \\
\hline An abnormalincrease of expencesandpurchaseperiodicallyoccurs. & 184 & 2,5 & 1,3 \\
\hline Documents not recorded on time periodicallyoccur. & 184 & 3,4 & 1,5 \\
\hline Thecorrectiondeclaration is periodicallygiventothetaxoffice & 184 & 3,7 & 1,5 \\
\hline Undocumentedrecordsperiodicallyoccur. & 184 & 3,7 & 1,2 \\
\hline Recordsbychangingtheamount on thedocumentperiodicallyoccur. & 184 & 4,2 & 1,2 \\
\hline Recordsbased on fraudulentdocumentsperiodicallyoccur. & 184 & 3,9 & 1,1 \\
\hline Imaginaryadvancerecordsforpartnersandemployeesperiodicallyoccur. & 184 & 3,2 & 1,4 \\
\hline Staff has beentricking on recordsanddocumentswehave had. & 184 & 4,2 & 1,3 \\
\hline Punishmentsduetoerrorsperiodicallyoccur. & 184 & 3,9 & 1,1 \\
\hline
\end{tabular}

Table-3 showsitems in thequestionnairewiththeirmeanandstandarddeviations. Allmeanvaluesareout of 5 andinterpretedaccordingtotheplace on thescale. Since 3 is at thecenter of thescaleandrepresents "undecided" opinion, meanscoresgreaterthan 3 areinterpretedtowards "agree" andmeanscoreslessthan 3 areinterpretedtowards "disagree". It can be seenthatmost of themeanscoresaregreaterthan 3 andparticipants'opinionsaremarkedly "agree" foreachitem. Instead of evaluatingitemsonebyone, usingthe general descriptivestatistics of all has beenpreferredforevaluation.

The mean of all items has been found as 3,48 . This value is close to 4 which represents "agree". The standard deviation is also low and it shows that participants are very homogenious in terms of their gradings. Then, the mean represents the opinion well.If the meaning of the questionnaire is thought by this sentence "There are fraud and corruption in our enterprise.", we could interpret observed SMEs to agree this opinion. Thus, it could be thought that the existence of having an effective internal control system problem in SMEs has been verified. Therefore, SMEs as well have the need to establish an internal control system corresponding to their structures in accordance with fundamental principles such as risk prevention, relevant cost, an effective and rapid operation and a continuously supervised structure. Finally, to determine the role of existence an auditing committee to prevent the fraud, an independence samples $t$ test was applied and findings are given in Table 4 .

Table-4Independent Samples t-Test Results

\begin{tabular}{|l|l|l|l|l|l|}
\hline Internalcontrolcommittee & $\mathrm{N}$ & Mean & Std. Deviation & t & $\mathrm{P}$ \\
\hline existed & 105 & 3,27 & 0,64 & 8,146 & 0,000 \\
\hline non-existed & 75 & 4,36 & 1,13 & & \\
\hline
\end{tabular}

When we compare mean values, there is a statistically significant difference between SMEs with an internal control committee and without an internal control committee (since $p<0,05$ ). The mean of SMEs with 
internal control committee is lower $(3,27<4,36)$ and they encounter the fraud event less than SMEs without an internal control committee. So, by the existence of internal control committee and an effective internal control system fraud could be prevented.The compliance with regulations and legislations will aid an enterprise with its institutionalization and reliability whereas the presence andoperability of internal control system will help in the efficiency and productivity of operations.

It is not possible to create an internal control system that will eliminate the risks completely and will comply with all enterprises in terms of theaccountingfunction, just as in all functions of the enterprise.Nonetheless, minimizing these risks with a well-functioning internal control systemshould be an obligation for all enterprises, no matter what their size is.

The results obtained have brought out to a what extent the internal control system is important for SMEs, being based objectively on the numerical analysis, and stated the attitudes of SME owners, managers and officials regarding how influential the internal control is in both accounting process, and overall fraud and corruption prevention. In accordance with the recommendations mentioned above, this study hopes both to make a contribution to the operation of SMEs and to provide an ideain terms ofliterature and methodology to the individuals or institutions that will conductresearch in the related fields of study.

\section{References}

[1] Amudo A., Inanga E. L. (2009). Evaluation of Internal Control Systems: A Case Study From Uganda. International Research Journal of Finance and Economics, 27: 124

[2] Aksoy, T. (2007). DerecelendirmeSüreciIşı̆ğında Basel H'ninKOBİ'lereEtkileriveKOBİ'lerceAtılmasıGerekenAdımlar: AnalitikBirBakış. [The Effects of Basel H on SMEs in the Light of Grading Process and the Steps to Be Taken by SMEs: An Analytic Glance] Mali Çözüm, 84,81

[3] Argun D. Biçer A.A. (2009). "Türkiye'deKobilerinDenetimindeYaşananZorluklarveÇözümÖnerileri"[Difficulties in Inspections of SMEs in Turkey and Solution Suggestions], Türkiye 9.Muhasebe DenetimiSempozyumu, s.4

[4] Atmaca, M, (2012), 'MuhasebeSkandallarınınÖnlenmesindeİçKontrolSistemininEtkinleştirilmesi' [Activation of Internal Control System in Prevention of Accounting Scandals], AfyonKocatepe Üniversitesi, İIBF Dergisi, C.XIV, S I, ss.191-204.

[5] Bowen, M., Morara, M., \&Mureithi, S. (2009). Management of businesschallengesamongsmallandmicroenterprises in NairobiKenya. KCA journal of businessmanagement, 2(1), 16-31.

[6] Cabarrouy, E.A.(1999), 'The Importance Of The Non-State Micro-Enterprise In Improving The Productive Capacity Of The Cuban Economy', An International Symposium: The Cuban Economy: Problems, Policies, and Perspectives, September 28-30.

[7] COSO, (2015),http://www.coso.org/aboutus.htm, (access: 08.03.2016).

[8] Çelik, A. \&Akgemici, T. (2010), YönetimBilişimSistemleri [Management Information Systems], Ankara: GaziKitabevi.

[9] Eric L Hyman (1989). The role of small- andmicro-enterprises in regionaldevelopment, Project Appraisal, 4:4, 197-214, DOI: 10.1080/02688867.1989.9726734

[10] Foster, B. P., McClain, G., \&Shastri, T. (2010). Impact on pre-and post-sarbanesoxley users' perceptions by incorporating the auditor's fraud detection responsibility into the auditor's internal control report. Research in Accounting Regulation, 22(2), 107113 .

[11] Gjini, K. (2014). Small AndMediumSizedEntreprises; GrowthFactors. EuropeanScientificJournal.

[12] J. Roberts (2015). The 'subject' of corruption'Crit. Perspect. Acc., 28 (2015), pp. 82-88.

[13] Kalm $\square \square$, H., Eskin, $\square$., Gümü $\square$, F(2006), 'Işsletmelerde Mali BilgilerÜretilmesininÖnemiveEtik’ [The Importance of Financial Information Production and Ethics in Enterprises], Mali Çözüm SMMMO YayınOrganı, (75): ss.141-160.

[14] Manurung, D., Suhartadi, A. R., \&Saefudin, N. (2015). The Influence of Organizational Commitment on Employee Fraud with Effectiveness of Internal Control and Organizational Justice as a Moderating Variable. Procedia-Social and Behavioral Sciences, 211, 1064-1072.

[15] Nicolescu, C. (2007). Spălareabanilor: maimulterepereîntr-o lumeatipică. EdituraUniversităţii" Lucian Blaga".

[16] Othman, R., Aris, N. A., Mardziyah, A., Zainan, N., \& Amin, N. M. (2015). Fraud Detection and Prevention Methods in the Malaysian Public Sector: Accountants' and Internal Auditors' Perceptions. Procedia Economics and Finance, $28,59-67$.

[17] Petra $\square$ cu, D., \&Tieanu, A. (2014). The Role of Internal Audit in Fraud Prevention and Detection. Procedia Economics and Finance, 16, 489-497.

[18] R Hunt, (1983).The Evaluation of Small Enterprise Programs andProjects: Issues in Business andCommunity Development (Washington, DC, US Agencyfor International Development).

[19] Ramos, M.(2003). Auditors' responsibility for fraud detection. Journal of Accountancy, 195(1), 28-36.

[20] Ren, S., Eisingerich, A.B., Tsai, H.T. (2014), How do marketing, research and development capabilities, and degree of internationalization synergistically affect the innovation performance of small and medium-sized enterprises (SMEs)? A panel data study of Chinese SMEs. International Business Review, 24(4), 642-651.

[21] Robson, P. J., Haugh, H. M., \&Obeng, B. A. (2009).Entrepreneurshipandinnovation in Ghana: enterprisingAfrica. Small Business Economics, 32(3), 331-350.

[22] Sal $\square$, S. (2015), İşletmeYönetimindeMuhasebeninÖnemi [The Importance of Accounting in Enterprise Management], http://archive.ismmmo.org.tr/docs/malicozum/23MaliCozum/07-SADETTIN\%20SALIK32.doc, (access: 18.04.2015).

[23] Sgardea F. M. (2009). Risk Management and The Internal Control Systems Promoted by COSO in The Context of Financial Crisis. Metalurgia International, 14 (15): 54

[24] Stolowy, H., \& Breton, G. (2004). Accounts manipulation: A literature review and proposed conceptual framework. Review of Accounting and Finance, 3(1), 5-92.

[25] Türedi, H., Zor, Ü.G., Gürbüz, F. (2015). Risk Odaklı̇̇çDenetim [Risk Oriented Internal Audit], MuhasebeVeFinansmanDergisi, Nisan, s.3

[26] TiDE, (2010).UluslararasılçDenetimStandartları, UluslararasıMeslekiUygulamaÇerçevesi(UMUÇ) [International Internal Control Standards, International Professional Practice Frame], Ocak, s.155

[27] Zindiye, S. (2008). An impericalinvestigationintothefactorsaffectingtheperformance of smallandmediumenterprises in themanufacturingsector of Harare, Zimbabwe (Doctoraldissertation, University of Fort Hare). 